\title{
The origins of internal communication and employer branding in marketing theories $^{1}$
}

Review paper, DOI 10.22522/cmr20210163, received on 19 April 2021

UDK: $\quad 005.57: 005.95 / 96$

$330.1: 339.138$

\section{Dubravka Sinčić Ćorić, PhD, Full Professor (corresponding author)}

Faculty of Economics \& Business, University of Zagreb, Zagreb, Croatia.

E-mail: dsincic@efzg.hr

\section{Anja Špoljarić, Research Assistant}

Faculty of Economics \& Business, University of Zagreb, Zagreb, Croatia.

E-mail: aspoljaric@efzg.hr

\section{Abstract}

Internal communications and employer branding are recognized as important tools for achieving an inspirational working environment, which is both an aim and a means of differentiation between organisations. A growing number of studies demonstrate a connection between internal communication and employee identification with the organisation they work for, as well as with their perception of employer's brand. The aim of this theoretical paper is to identify and elaborate theoretical foundations that contributed to the development of these two concepts. For that purpose, marketing schools of thought, primarily social exchange school of marketing thought and relationship marketing are analysed and related to the concepts of internal communication, and employer branding. The analysis shows that social exchange school theories can be applied to describe values that are exchanged through internal communication and employer brand activities, while relationship marketing principles are used when implementing these activities in order to develop positive employee relationships.

Keywords: internal communication, employer branding, marketing theory, social exchange school, relationship marketing

1 This paper has been fully supported by the Croatian Science Foundation under project no. 3323. 


\section{Introduction}

Concepts such as internal communication and employer brand have been gaining popularity in the past decade, both in academia and in practice (Tkalac Verčič, 2021). The recent global crisis has further contributed to the recognition of their significance and contributions to organizations (Martić, 2020). This is no surprise considering internal communication includes all types of formal and informal communication taking place within an organization (Kalla, 2005). It also plays a significant role in daily and strategic activities (Welch, Jackson, 2007), which is the reason it gained even more momentum in times of overall business transformation that was required in the recent crisis. At the same time, in search for the best employees in today's competitive markets, organizations engage in different employer branding initiatives with an aim of becoming an employer of choice. Employer's brand includes all perceived benefits that come with employment (Ambler, Barrow, 1996) and create a desirable employer's image (Backhaus, Tikoo, 2004). Sobande (2020) recognizes that brands in general are communicating the idea of togetherness in order to stay desirable during a time of crisis. Employer brands are no different, and in order to stay desirable, organizations need to appeal to their current and potential employees to ensure their satisfaction even in extraordinary situations (Nelke, 2021). In that sense, the relationship between corporate and internal communications, and employer branding is recognized by many authors (e.g., Ambler, Barrow, 1996; Punjaisri et al., 2009; Edwards, 2010; Dryl, 2017; Itam et al., 2020).

Even though both internal communication and employer branding have been rapidly gaining importance in recent times, the origins of these concepts can be recognized in particular marketing schools of thought dating back to the middle of the 20th century.

In 1988, Sheth et al. proposed a two-dimensional matrix in order to classify marketing schools of thought. Their matrix classifies the schools as noninteractive versus interactive and economic versus noneconomic, which divides them into the four different categories shown in table 1. 
Table 1: Marketing schools of thought classification matrix by Sheth et al., 1988.

\begin{tabular}{|l|l|l|}
\hline \multirow{2}{*}{ Economic schools } & Noninteractive schools & Interactive schools \\
\hline \multirow{2}{*}{ Noneconomic schools } & Commodity & Institutional \\
\hline & Functional & Functionalist \\
\cline { 2 - 3 } & Regional & Managerial \\
\hline & Buyer Behaviour & Organizational Dynamics \\
\hline & Activist & Systems \\
\hline & Macromarketing & Social Exchange \\
\hline
\end{tabular}

Source: Sheth et al., 1988.

The centre of noninteractive-economic schools, the most traditional of all, are efficiency and income (Lagrosen, Svensson, 2006). Interactive-economic schools are still based on economic values, but are also influenced by psychological variables of buyer-seller interactions (Sheth et al., 1988). Noninteractive-noneconomic schools suggest that markets are based on social and behavioural factors (Lagrosen, Svensson, 2006). A shift is made from markets to customers as individuals or segments (Sheth et al., 1988). Interactivenoneconomic schools combine an interactive approach to the market (Sheth et al., 1988) and transactions, not necessarily motivated by profit gain, but rather (needs) satisfaction (Houston, Gassenheimer, 1987).

However, three new schools (services marketing, industrial (B2B) marketing and relationship marketing) identified by Lagrosen and Svensson (2006) are so diverse from traditional marketing schools they require a new direction recognition. Therefore, they suggest interactive schools further be categorized into transactional and relational. This way they classify interactive schools analysed and categorized by Sheth et al. (1988) as a part of the transactional dimension, while new schools can be classified as relational-noneconomic schools.

Although both internal communication and employer branding have received a lot of attention from academics, there is a lack of papers investigating the theoretical origins of these concepts. This paper contributes to the body of knowledge by exploring internal communication and employer branding from the viewpoint of their theoretical origins in the foundations of the social exchange school of marketing thought and relationship marketing.

The paper is organised in the following way: after the introductory part, the main highlights of the social exchange school of marketing thought and relationship marketing principles are explained. After that, an overview of internal communication and employer brand(ing) 
concepts is provided. This is followed by a discussion in which the links between the concepts and their theoretical origins are debated. The paper ends with concluding remarks.

\section{Marketing schools of thought in focus: The ideas of social exchange and relationships in marketing}

\subsection{Social exchange school}

The social exchange school of marketing thought can be classified as interactive-noneconomic school of marketing thought (Sheth et al., 1988) or, more specifically, as transactional-noneconomic school of marketing thought (Lagrosen, Svensson, 2006). This school approaches the consumers as equals to providers of goods while also relying on behavioural science for background, suggesting that marketing principles are applicable beyond the usual economic transactions and can be applied to social transactions (Kotler, Levy, 1969; Lagrosen, Svensson, 2006; Sheth et al, 1988), an idea first introduced by Alderson in 1965. He stated that "marketing [academics] are working in an applied segment ... of a general science of human behaviour" (as cited in Shaw et al., 2007, p. 446). A year prior, McInnes broadened the scope of marketing by suggesting that marketing is "any activity which actualizes the potential market relationship between the makers and users of economic goods and services" (McInnes, 1964, as cited in Kuehl, 1972, p. 360; McInnes, 1964, as cited in Sheth et al., 1988, p. 174). They are considered to share the role of originators for the social exchange school due to their individual contributions to marketing theory (Sheth et al., 1988).

Kotler and Levy (1969) followed these ideas and described the applicability of marketing principals beyond a mere product exchange by suggesting a broader scope of marketing. According to them ".... marketing principles are transferable to the marketing of organizations, persons, and ideas” (p. 10). As Bagozzi (1978) explained, Kotler and Levy's broader scope of marketing meant marketing principles are present in "virtually all organizations, groups, or collectivities" (p. 536). In 1972, Kotler suggested an even more expanded scope of marketing. He argued that marketing activities should and could be applied to relationships between an organization and all its publics, not just customers. In his generic concept of 
marketing, Kotler (1972) also expanded the idea of transactions to include the exchange of any types of resources between all types of parties. This resulted in the idea that "marketing applies to any social unit seeking to exchange values with other social units" (p. 53), which is exactly the idea behind the social exchange school.

Later on, Bagozzi (1974) gave a comprehensive definition of exchange, which stated that both positive and negative actions should be considered an exchange. He also made an emphasis on social processes as determinants of exchange, which should not be considered as limited concepts. Furthermore, in 1978, Bagozzi continued redefining the theory of exchange as a social process. As he suggested, exchange is not limited to an individual's decisions and is determined by: exchange participants' characteristics, exchange participants' influence and situation. His efforts to define exchange as a foundation of marketing were continued by Hunt. Hunt (1983) stated: "marketing science is the behavioural science that seeks to explain exchange relationship" (p. 13). Exchange relationships were the basis of a model Hunt (1983) gave to explain the nature of marketing. This idea was further supported by Houston and Gassenheimer (1987), who have identified exchange as "the core concept of marketing". It is so because exchange is the means to "satisfy needs".

The exchange school was originally focusing on sellers and buyers, and their market transactions and transvections. It has, however, broadened to include all parties involved in a generic exchange relationship, regardless of roles, motives or values (Shaw, Jones, 2005). Nevertheless, Sheth et al. (1988) critique the social exchange school for not providing enough explanation as to why exchange happens. They are also concerned by the generic concept of marketing which "created ambiguity as to the boundary of marketing" (p. 180). It is exactly this generic approach that authors believe affected the fields of internal communication and employer branding the most.

\subsection{Relationship marketing}

In the late 1970s and early 1980s, new streams in marketing theory emerged that shifted away from traditional marketing principles (Brown et al., 1994). At first, industrial and services marketing dealt with marketing in regards to their specific area (Lagrosen, Svensson, 2006). However, one common factor was the importance of relationships, which led to theories concerning relationship marketing (Gummesson, 1987; Lagrosen, Svensson, 
2006). The importance of relationships in the service sector was indicated by Berry (1983, as cited in Ballantyne et al., 2003). Gummesson (1987) went further and described the central importance of relationships between an organization and its customers, as well as within an organization's network of suppliers and distributors. Relationship marketing theory was developed after the importance of organization-to-customer relations and businessto-business (B2B) relations was recognized (Ballantyne et al., 2003), as a consequence of services marketing theory and industrial marketing theory development (Gummesson, 1987). In regards to its connection to services marketing, relationship marketing had two goals - to attract and to retain the customers (Christopher et al., 1991). In the context of industrial marketing, relationship marketing is a tool that helps create interactive networks between partner organizations defined by reciprocal actions (Möller, 1994). It is a part of modern marketing theories and can be classified as relational-noneconomic school of marketing thought (Lagrosen, Svensson, 2006).

In 1999, Gummesson identified additional influences that affected relationship marketing, such as traditional marketing and management theories, business marketing, and organization theory. Considering this, it is no surprise relationship marketing principles have expanded to marketing areas other than services and industrial marketing (O’Malley, Tynan, 2000). Bruhn (2003) has identified four types of orientation - toward stakeholders, decisions, time-horizon and, value, which he deems are relationship marketing dimensions. This expanded approach that reaches beyond services and industrial marketing theories has also revealed some new findings. As Dwyer et al. (1987) explained, exchange is the basis of marketing, however, there are two different aspects of it - transactional and relational exchanges. The relational aspect develops over time (Dwyer et al., 1987; Gummesson, 1987; O’Malley, Tynan, 2000; Tynan, 1997) and, just as with interpersonal relationships, some psychological concepts (e.g. trust, commitment, interdependence, power balance) can be used to describe it (Morgan, Hunt, 1994; Wilson, 1995). All this has led to the development of a new approach within relationship marketing, customer relationship management (CRM). This approach combines relationship marketing principles with new technologies in order to develop interactive relationships with customers (Kumar, 2010). However, some authors consider CRM to be more generic and see it as just another term for relationship marketing (Lagrosen, Svensson, 2006). Even so, it is evident that newer trends in relationship marketing include technology. Gârdan (2011) deems the internet to be the main trend in 
present-day relationship marketing, as well as the development of strategic partnerships between brands that bring value to consumers.

Relationship marketing principles can be recognized in internal communication and employer branding. Both internal communication and employer branding activities are used to create relationships between an organization and its publics (Cascio, Graham, 2016; Men, 2014; Men, Yue, 2019).

\section{Overview of Internal communication \& Employer brand(ing) concepts}

\subsection{Internal communication}

In terms of organizations, communication can be intended for either internal, in which case it is called internal communication, or external publics, in which case it is called external communication (Cornelissen, 2004).

Internal communication includes all communication within an organization (Kalla, 2005; Tkalac Verčič et al., 2012). It is present constantly (Welch, Jackson, 2007) between members of an organization (Réka, Borza, 2012). According to Bovée and Thill (2008), internal communication consists of all formal and informal communication flows in an organization. Bahtijarević-Šiber and Sikavica (2001) see it as the exchange of different information, ideas, attitudes and emotions with the purpose of influencing employees' behaviour. It is important to recognize that internal communication takes place at all organizational levels (Kalla, 2005). Internal communication "is viewed as an essential process, based on which the staff exchanges information, establishes relationships, forms a system of values, creates an organizational culture, harmonizes the activities, collaborates for the achievement of goals and develops formal and informal networks” (Berger, 2009, as cited in Réka, Borza, 2012, p. 615).

Communication in general is the exchange of all sorts of information (Bovée, Thill, 2008; Hersberger et al., 2007). Information can be contextual (or nonverbal) and verbal (Burgoon et al., 2002), which means communication can be defined as the exchange of different types of verbal and nonverbal cues (Bovée, Thill, 2008; Burgoon et al., 2002; Hersberger et al., 2007). Wilkinson et al. (2004) put such emphasis on exchange as a crucial part of internal 
communication that they even equate one aspect of internal communication with the exchange of views.

The first to describe the benefits of quality communication within an organization was Likert in 1967, who established that communication leads to satisfaction, productivity, good relations and profit (as cited in Downs, Hazen, 1977). In his research, Hansen (1986) determined that relationships between employees are the most significant predictor of profitability (as cited in Robson, Tourish, 2005), while internal communication is used to create those relationships (Men, Yue, 2019). When describing relational aspects of marketing, Gummesson (1987) stated that internal relations are "a prerequisite for successful external relations" (p. 12). Quin and Hargie (2004) have also linked organizational efficiency to relationships within an organization, which are created through communication. The overall importance of internal communication and its positive contributions to internal relationships and organizational success has been recognized by many researchers (e.g. Dryl, 2017; Gray, Laidlaw, 2004; Mazzei, 2010; Ruck, Welch, 2011; Sinčić Ćorić et al., 2020; Tkalac Verčič, 2021; Tkalac Verčič, Pološki Vokić, 2017; Tkalac Verčič et al., 2009; Tkalac Verčič, Špoljarić, 2020; Tkalac Verčič et al., 2012; Welch, 2012; Zucker, 2002).

\subsection{Employer brand(ing)}

Branding is the process of creating a brand (Vaid, Campbell, 2003), which is a set of values associated with a specific product/service in order to differentiate it from other products/services (Levitt, 1980; Kotler, 1997). However, it has recently been recognized that the objects of branding can be more than mere products or services (Barrow, Mosely, 2011). One of the more recent branding objects are employers. Employer brand was first described in 1996 by Ambler and Barrow as "the package of functional, economic and psychological benefits provided by employment, and identified with the employing company" (p. 187). Employer brand can also be described as a set of positive and negative associations linked to an employer (Mosely, 2014). Potential and current employees can also see it as a sum of an employer's reputation and purpose together with opportunities employment offers (Chinsky Matuson, 2013).

The process of developing an employer brand is employer branding (Backhaus, Tikoo, 2004). The goal of developing and managing an employer brand is to attract employees (Rampl, 2014) by communicating the benefits it offers (Barrow, Mosley, 2011). The developed perception of 
employer brand benefits describe employees' expectations from their employment (Barrow, Mosley, 2011). Benefits promised by the employer brand are received in exchange for employees' work (Alshathry et al., 2017; Cardy et al., 2007). One of the most crucial tasks of employer branding is to align perceived benefits with actual benefits offered by employment (Ruchika, Prasad, 2017; Backhaus, Tikoo, 2004), which is done through communication of the employer brand. For an employer brand to be communicated properly, communication needs to target both current employees, i.e. internal publics, and potential employees, i.e. external publics (Moroko, Uncles, 2008; Ruchika, Prasad, 2017). This means both internal and external communication communicate employer brands. Researchers identified that employer brands are therefore created internally and externally and are intercorrelated, but not the same (Knox, Freeman, 2006; Mellin, 2005). Employees are seen as "corporate ambassadors and brand advocates" (Men, 2014, p. 265; see also Men, Graham, 2016), which means external employer brand is created with the help of current employees. They are more likely to be positive ambassadors if they are satisfied with their employer, i.e. if internal employer brand is positive (Backhaus, 2018).

\section{Discussion}

\subsection{Internal communication and employer brand(ing) through social exchange perspective}

Both internal communication and employer branding are highly interactive fields (Tkalac Verčič, 2016; Cascio, Graham, 2016; Men, 2014). Internal communication requires high levels of interactivity since one of the main internal communication activities is listening to employees and communication culture development (Mazzei, 2010; Zerfass, Franke, 2013). Successful employer brand requires employees to be brand ambassadors (Cascio, Graham, 2016; Backhaus, 2018; Men, 2014) and to engage (Bhasin et al., 2019), both highly interactive activities. Interactivity is one of two key elements that describe social exchange school (Sheth et al., 1988).

The focus of the social exchange school is noneconomic - unlike economic schools of marketing thought, the social exchange school is not focused on income and efficiency, but rather on aspects of human behaviour (Sheth et al., 1988). The same applies to both internal 
communication and employer branding. These fields contribute to economic organizational success, but are focused on employees' satisfaction (Sinčić Ćorić et al., 2020; Tkalac Verčič, 2021; Tkalac Verčič, Špoljarić, 2020).

The idea behind the social exchange school is that marketing principles are applicable to social transactions (Alderson, 1965 as cited in Shaw et al., 2007; Kotler, Levy, 1969; Lagrosen, Svensson, 2006; Sheth et al, 1988). Kotler (1972) went as far as to claim that marketing should consider transactions to be any type of exchange of values. In terms of internal communication, values that are exchanged are information, ideas, attitudes and emotions (BahtijarevićŠiber, Sikavica, 2001). Itam et al. (2020) describe that the messages sent to employees about employer brand and value proposition should not only deliver the information related perks and benefits, but also the organization's mission, values and culture, which give employees a powerful reason to work with the company in the long run. Those values are mostly social, especially ideas, attitudes and emotions. Formal or managed internal communication is the exchange of strategically established values (Welch, Jackson, 2007) with the intent of ensuring employees' satisfaction and productivity (Likert, 1967, as cited in Downs, Hazen, 1977). In order to manage formal internal communication, managers apply marketing principles to develop strategies and ensure communication goals are achieved. On the other hand, informal internal communication answers employees' social needs (Johnson et al., 1994). The end-results of informal, together with some aspects of formal, exchanges are good relations between employees as well as a positive relationship with the organization itself (Azadedel, Shokri, 2019), i.e. higher organizational identification (Neill et al., 2020). Informal internal communication requires marketing principles to be applied while promoting a desirable communication climate within the organization and supporting the exchange of values in an informal environment in order to achieve organizational identification (Neill et al., 2020). Organizational identification can also be linked to internal employer brand perception (Charbonnier-Voirin et al., 2017; Lievens et al., 2007). It describes employees' cognitive perception of how much they associate themselves with the organization (Ashforth, Mael, 1989). It is a specific form of social identification (Lievens et al., 2007), achieved through the exchange of appropriate employer brand values. However, it is important to note an even more significant foundation the social exchange school laid for employer branding. The employer branding definition itself states that it is the management of perception of different types of benefits employees receive in exchange for their work (Alshathry et al., 2017; Ambler, Barrow, 1996; 
Cardy et al., 2007) and essentially describes using marketing principles in terms of both social and economic exchanges. When it comes to the psychological benefits employees receive for their work (Ambler, Barrow, 1996), those can be considered as entirely social exchanges.

\subsection{Internal communication and employer brand(ing) through the relationship marketing perspective}

Just like the social exchange school, relationship marketing is highly interactive and is not economically oriented (Lagrosen, Svensson, 2006). However, the focus of relationship marketing are relationships. Relationship marketing proposes the application of marketing principles in order to manage relationships between an organization and all its publics (Bruhn, 2003; O’Malley, Tynan, 2000). Both internal communication and employer branding activities and techniques are used to develop and maintain relationships between organizations and their employees (Ambler, Barrow, 1996). If these relationships are managed well, they can contribute to employees' satisfaction, which in turn contributes to overall organizational performance (Barrow, Mosely, 2005; Likert, 1967, as cited in Downs, Hazen, 1977). Internal communication helps create these relationships (Men, Bowen, 2017) while employer brand also has an influence in forming them through "awareness, positive attitudes toward the 'brand', loyalty and trust that the 'brand' is there for the employee" (Ambler, Barrow, 1996, p. 185).

Even in 1967, Likert recognized the creation of good relationships as one of the benefits of communication (as cited in Downs, Hazen, 1977). Men and Yue (2019) agree. A strategic approach to internal communication leads to quality relationships within the organization (Gruning, 1992, as cited in Men, Yue, 2019). According to Men and Bowen (2017), creating mutually beneficial relationships between an organization and its employees is the main goal of internal communication. Those relationships are shaped through formal internal communication, but also through informal internal communication by creating and sharing organizational values, consideration of culture, as well as different employee groups' needs (Welch, 2011). Linke and Zerfass (2011) state that the quality of internal communication is crucial for organizations, since it can improve organizational effectiveness by improving internal relationships (Welch, 2012).

Even when they first defined it, Ambler and Barrow (1996) recognized employer branding as a discipline of relationship marketing. As they see it, employees develop close relationships with 
their employing organization's brand. They found that employee relationships are defined by trust, commitment, shared values, and longevity of relationships, just like relationship marketing. Alshathry et al. (2017) claim that employer brand value is delivered through employee relationships. These relationships are described as either positive or negative, depending on employees' experiences of exchanging and receiving the benefits from employer (Cardy et al., 2007). In order to ensure these relationships are positively perceived, all the defining elements (i.e. trust, commitment, shared values, and longevity of relationships) need to be managed appropriately, which means organizations need to ensure their employer brands are perceived adequately (Alshathry et al., 2017; Ambler, Barrow, 1996).

\section{Concluding remarks}

Internal communication and employer branding are recognized as important tools for achieving an inspirational working environment. This is even more emphasised due to the recent global pandemic crisis, which provokes overall business transformation.

There are many studies corroborating the importance and the connection between internal communication and employer branding activities, as well as their practical benefits for organisations. Studies have shown that there are many elements vital for the positive evaluation of an employer brand, like good products' or corporate reputation (Arachchige, Robertson, 2011; Itam et al., 2020; Kissel, Büttgen, 2015); inspiring working environment (Schlager et al., 2011), appealing compensation systems (Moroko, Uncles, 2008) etc., as well as effective internal communication, which plays a central role in disseminating messages about company values to present and future employees (Neill, 2016). Even so, there is a lack of papers examining the theoretical origins of these concepts. Therefore, the main contribution of this paper is the analysis of theoretical origins that have led to the development of the internal communication and employer branding concepts. The analysis shows that the exchange process typical for internal communication and employer brand activities has its roots in

social exchange school theories, while the implementation of these activities relies on the principles originating from relationship marketing. 


\section{References}

- Alshathry, S., Clarke, M., Goodman, S. (2017). The role of employer brand equity in employee attraction and retention: a unified framework. International Journal of Organizational Analysis, 25 (3), 413-431.

- Ambler, T., Barrow, S. (1996). The employer brand. Journal of brand management, 4 (3), 185-206.

- Arachchige, B. J. H., Robertson, A. (2011). Business Student Perceptions of a Preferred Employer: A Study Identifying Determinants of Employer Branding. The IUP Journal of Brand Management, 8 (3), 25-46.

- Ashforth, B. E., Mael, F. (1989). Social identity theory and the organization. Academy of management review, 14 (1), 20-39.

- Backhaus, K. (2018). People make the brand: a commentary. Management Research: Journal of the Iberoamerican Academy of Management, 16 (4), 380-387.

- Backhaus, K., Tikoo, S. (2004). Conceptualizing and researching employer branding. Career development international, 9 (5), 501-517.

- Bagozzi, R. P. (1974). Marketing as an Organized Behavioral System of Exchange: A comprehensive and analytic structure for interpreting behavior in marketing relationships. Journal of marketing, 38 (4), 77-81.

- Bagozzi, R. P. (1978). Marketing as exchange: a theory of transactions in the marketplace. American Behavioral Scientist, 21 (4), 535-556.

- Bahtijarević-Šiber, F., Sikavica, P. (2001). Leksikon menedžmenta [Management lexicon]. Masmedia.

- Ballantyne, D., Christopher, M., Payne, A. (2003). Relationship marketing: looking back, looking forward. Marketing Theory, $3(1), 159-166$.

- Barrow, S., Mosley, R. (2011). The employer brand: Bringing the best of brand management to people at work. John Wiley \& Sons.

- Bhasin, J., Mushtaq, S., Gupta, S. (2019). Engaging employees through employer brand: an empirical evidence. Management and Labour Studies, 44 (4), 417-432.

- Bovée, C. L., Thill, J. V. (2008). Business Communication Today (9th ed.). Pearson Education Inc..

- Brown, S. W., Fisk, R. P., Bitner, M. J. (1994). The development and emergence of services marketing thought. International journal of service industry management, 5 (1), 21-48.

- Bruhn, M. (2003). Relationship marketing: Management of customer relationships. Pearson Education.

- Burgoon, J. K., Bonito, J. A., Ramirez Jr, A., Dunbar, N. E., Kam, K., Fischer, J. (2002). Testing the interactivity principle: Effects of mediation, propinquity, and verbal and nonverbal modalities in interpersonal interaction. Journal of communication, 52 (3), 657-677.

- Cardy, R. L., Miller, J. S., Ellis, A. D. (2007). Employee equity: Toward a person-based approach to HRM. Human Resource Management Review, 17 (2), 140-151.

- Cascio, W. F., Graham, B. Z. (2016). New strategic role for HR: Leading the employer-branding process. Organization Management Journal, 13 (4), 182-192.

- Charbonnier-Voirin, A., Poujol, J. F., Vignolles, A. (2017). From value congruence to employer brand: Impact on organizational identification and word of mouth. Canadian Journal of Administrative Sciences/Revue Canadienne des Sciences de l'Administration, 34 (4), 429-437.

- Chinsky Matuson, R. (2013). Talent magnetism: how to build a workplace that attracts and keeps the best. Hachette UK.

- Christopher, M., Payne, A., Ballantyne, D. (1991). Relationship marketing: bringing quality customer service and marketing together. Unpublished paper. Retrieved from dspace.lib.cranfield.ac.uk [Cranfield CERES], Cranfield University.

- Cornelissen, J. P. (2004). Corporate communication: Theory and practice. Sage Publications.

- Downs, C. W., Hazen, M. D. (1977). A factor analytic study of communication satisfaction. The Journal of Business Communication (1973), 14 (3), 63-73.

- Dryl, T. (2017). Internal branding in organization in the context of internal corporate communication. Handel Wewnętrzny, 2, 56-68.

- Dwyer, F. R., Schurr, P. H., Oh, S. (1987). Developing buyer-seller relationships. Journal of marketing, 51 (2), 11-27.

- Edwards, M. R. (2010). An integrative review of employer branding and OB theory. Personnel Review, 39 (1), 5-23.

- Gârdan, D. A. (2011). New perspectives in relationship marketing conceptualization. Annals of Spiru Haret University, Economic Series, 2 (11), 81-9.

- Gray, J., Laidlaw, H. (2004). Improving the measurement of communications satisfaction. Management Communication Quarterly, 17 (3), 425-448.

- Gummesson, E. (1987). The new marketing-developing long-term interactive relationships. Long range planning, 20 (4), $10-20$. 
- Gummesson, E. (1999). Total relationship marketing: experimenting with a synthesis of research frontiers. Australasian Marketing Journal (AMJ), 7 (1), 72-85.

- Hersberger, J. A., Murray, A. L., Rioux, K. S. (2007). Examining information exchange and virtual communities: an emergent framework. Online Information Review, 31 (2), 135-147.

- Houston, F. S., Gassenheimer, J. B. (1987). Marketing and exchange. Journal of marketing, 51 (4), 3-18.

- Hunt, S. D. (1983). General theories and the fundamental explananda of marketing. Journal of marketing, 47 (4), 9-17.

- Itam, U., Misra, S., Anjum, H. (2020). HRD indicators and branding practices: a viewpoint on the employer brand building process. European Journal of Training and Development, 44 (6/7), 675-694.

- Johnson, J. D., Donohue, W. A., Atkin, C. K., Johnson, S. (1994). Differences between formal and informal communication channels. The Journal of Business Communication (1973), 31 (2), 111-122.

- Kalla, H. K. (2005). Integrated internal communications: a multidisciplinary perspective. Corporate Communications: An International Journal, 10 (4), 302-314.

- Kissel, P., Büttgen, M. (2015). Using social media to communicate employer brand identity: The impact on corporate image and employer attractiveness. Journal of Brand Management, 22 (9), 755-777.

- Knox, S., Freeman, C. (2006). Measuring and managing employer brand image in the service industry. Journal of Marketing Management, 22 (7-8), 695-716.

- Kotler, P. (1972). A generic concept of marketing. Journal of marketing, 36 (2), 46-54.

- Kotler, P. (1997). Marketing management: analysis, planning, implementation, and control (9th ed.). Prentice-Hall.

- Kotler, P., Levy, S. J. (1969). Broadening the concept of marketing. Journal of marketing, 33 (1), 10-15.

- Kuehl, P. G. (1972). Marketing perspectives for "ERIC-like” information systems. Journal of the American Society for Information Science, 23 (6), 359-364.

- Kumar, V. (2010). Customer relationship management. In: Sheth, J. N., Malhotra, N. K. (Eds.), Wiley international encyclopedia of marketing (pp. 405-421). John Wiley \& Sons, Ltd.

- Lagrosen, S., Svensson, G. (2006). A seminal framework of marketing schools: revisited and updated. Journal of Management History, 12 (4), 369-384.

- Levitt, T. (1980). Marketing success through differentiation - of anything. Harvard Business Review,_58, 89-91.

- Lievens, F., Van Hoye, G., Anseel, F. (2007). Organizational identity and employer image: Towards a unifying framework. British Journal of Management, 18, S45-S59.

- Linke, A., Zerfass, A. (2011). Internal communication and innovation culture: developing a change framework. Journal of Communication Management, 15 (4), 332-348.

- Martić, K. (2020, May 12). How to Keep Your Employer Brand Strong During and After the COVID-19 Crisis. Smarp. Retrieved from: https://blog.smarp.com/employer-brand-during-and-after-crisis, July 102021.

- Mazzei, A. (2010). Promoting active communication behaviours through internal communication. Corporate Communications: An International Journal, 15 (3), 221-234.

- Mellin, E. (2005). Employer branding: likenesses and differences between external and internal employer brand images. [Master's Thesis, Luleå Institute of Technology]. DiVA. Retrieved from: https://www.diva-portal.org/smash/record.jsf?pid=diva2\%3 A1030734\&dswid=-1517, July 102021.

- Men, L. R. (2014). Strategic internal communication: Transformational leadership, communication channels, and employee satisfaction. Management communication quarterly, 28 (2), 264-284.

- Men, L. R., Bowen, S. A. (2016). Excellence in internal communication management. Business Expert Press.

- Men, L. R., Yue, C. A. (2019). Creating a positive emotional culture: Effect of internal communication and impact on employee supportive behaviors. Public relations review, 45 (3), 101764.

- Möller, K. K. (1994). Interorganizational marketing exchange: metatheoretical analysis of current research approaches. Research traditions in marketing, 347-382.

- Morgan, R. M., Hunt, S. D. (1994). The commitment-trust theory of relationship marketing. Journal of marketing, 58 (3), 20 -38.

- Moroko, L., Uncles, M. D. (2008). Characteristics of successful employer brands. Journal of brand management, 16 (3), $160-175$.

- Mosley, R. (2014). Employer brand management: practical lessons from the world's leading employers. John Wiley \& Sons.

- Neill, M. S. (2016). The Influence of Employer Branding in Internal Communication. Research Journal of the Institute for Public Relations, 3 (1), 1-25.

- Neill, M. S., Men, L. R., Yue, C. A. (2019). How communication climate and organizational identification impact change. Corporate Communications: An International Journal, 25 (2), 281-298. 
- Nelke, A. (2021). Impact of the COVID-19 pandemic on corporate employer branding. Technium Social Sciences Journal, $16,388-393$.

- O’Malley, L., Tynan, C. (2000). Relationship marketing in consumer markets-rhetoric or reality? European Journal of marketing, 34 (7), 797-815.

- Punjaisri, K., Evanschitzky, H., Wilson, A. (2009). Internal branding: an enabler of employees' brand-supporting behaviours. Journal of Service Management, 20 (2), 209-226.

- Quinn, D., Hargie, O. (2004). Internal communication audits: a case study. Corporate Communications: An International Journal, 9 (2), 146-258.

- Réka, K., Borza, A. (2012). Internal and external communication within cultural organizations. Management \& Marketing, 7 (4), 613-630.

- Robson, P. J., Tourish, D. (2005). Managing internal communication: an organizational case study. Corporate Communications: An International Journal, 10 (3), 213-222.

- Ruchika, Prasad, A. (2019). Untapped relationship between employer branding, anticipatory psychological contract and intent to join. Global Business Review, 20 (1), 194-213.

- Ruck, K., Welch, M. (2012). Valuing internal communication; management and employee perspectives. Public relations review, 38 (2), 294-302.

- Schlager, T., Bodderas, M., Maas, P., Cachelin, J. L. (2011). The influence of the employer brand on employee attitudes relevant for service branding: an empirical investigation. Journal of Services Marketing, 25 (7), 497-508.

- Shaw, E. H., Jones, D. G. B. (2005). A history of schools of marketing thought. Marketing Theory, 5 (3), 239-281.

- Shaw, E. H., Lazer, W., Pirog III, S. F. (2007). Wroe Alderson: father of modern marketing. European Business Review, 19 (6), 440-451.

- Sheth, J. N., Gardner, D. M., Garrett, D. E. (1988). Marketing Theory: Evolution and Evaluation. Wiley.

- Sinčić Ćorić, D., Pološki Vokić, N., Tkalac Verčič, A. (2020). Does good internal communication enhance life satisfaction? Journal of Communication Management, 24 (4), 363-376.

- Sobande, F. (2020). 'We're all in this together': Commodified notions of connection, care and community in brand responses to COVID-19. European Journal of Cultural Studies, 23 (6), 1033-1037.

- Tkalac Verčič, A. (2021). The impact of employee engagement, organisational support and employer branding on internal communication satisfaction. Public Relations Review, 47 (1), 102009.

- Tkalac Verčič, A., Pološki Vokić, N. (2017). Engaging employees through internal communication. Public Relations Review, 43 (5), 885-893.

- Tkalac Verčič, A., Špoljarić, A. (2020). Managing internal communication: How the choice of channels affects internal communication satisfaction. Public Relations Review, 46 (3), 101926.

- Tkalac Verčič, A., Pološki Vokić, N., Sinčić Ćorić, D. (2009). Razvoj mjernog instrumenta za procjenu zadovoljstva internom komunikacijom [Developing internal communication satisfaction questionnaire]. Društvena istraživanja, 18 (1-2), $175-202$.

- Tynan, C. (1997). A review of the marriage analogy in relationship marketing. Journal of marketing Management, 13 (7), 695-703.

- Vaid, H., Campbell, A. (2003). Branding. Watson-Guptill.

- Verčič, A. T., Verčič, D., Sriramesh, K. (2012). Internal communication: Definition, parameters, and the future. Public relations review, 38 (2), 223-230.

- Welch, M. (2011). The evolution of the employee engagement concept: communication implications. Corporate Communications: An International Journal, 16 (4), 328-346.

- Welch, M. (2012). Appropriateness and acceptability: Employee perspectives of internal communication. Public Relations Review, 38 (2), 246-254.

- Welch, M., Jackson, P. R. (2007). Rethinking internal communication: a stakeholder approach. Corporate communications: An international journal, 12 (2), 177-198.

- Wilkinson, A., Dundon, T., Marchington, M., Ackers, P. (2004). Changing patterns of employee voice: Case studies from the UK and Republic of Ireland. Journal of Industrial Relations, 46 (3), 298-322.

- Wilson, D. T. (1995). An integrated model of buyer-seller relationships. Journal of the academy of marketing science, 23 (4), 335-345.

- Zerfass, A., Franke, N. (2013). Enabling, advising, supporting, executing: A theoretical framework for internal communication consulting within organizations. International Journal of Strategic Communication, 7 (2), 118-135.

- Zucker, R. (2002). More than a name change - internal branding at Pearl. Strategic Communication Management, 6 (1), $24-27$. 


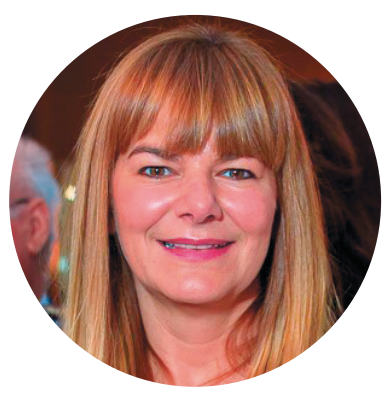

\section{Dubravka Sinčić Ćorić}

Dubravka Sinčić Ćorić is a full professor at the Department of Marketing, Faculty of Economics \& Business, University of Zagreb. She is also a director of the master's degree program in Marketing (in English) and the postgraduate study programme in Business-to-Business Marketing. Dubravka teaches Marketing, Marketing Management, and Businessto-Business (B2B) Marketing. She is an active researcher and author, and constantly leads or participates in international and national scientific or professional research projects. Dubravka is a member of the European Marketing Academy (EMAC) and a member of the main board of the Croatian marketing association CROMAR. She holds PhD and MBA diplomas from University of Zagreb, Faculty of Economics \& Business.

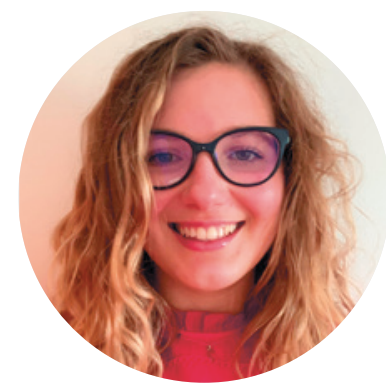

Anja Špoljarić

Anja Špoljarić is a research assistant working on a project funded by the Croatian Science Foundation dealing with internal communication and related concepts. She is a part of the Marketing Department at the Faculty of Economics and Business, University of Zagreb. She was awarded both her undergraduate (bachelor's) and graduate (master's) degrees at the Faculty of Economics and Business, University of Zagreb. She is a doctoral candidate and is currently pursuing a $\mathrm{PhD}$ in Business Economics at the Faculty of Economics and Business. In her doctoral studies, she is focusing on the field of public relations, more specifically on internal communication. 